\title{
MOSES IN THE BOOK OF DANIEL ${ }^{1}$
}

\author{
Hans van Deventer \\ North West University ${ }^{2}$
}

\begin{abstract}
In the Hebrew Bible, the name of Moses appears most frequently in the Hexateuch. Outside this corpus that is closely related to the life of this main character in the narrative, the name of Moses is found mostly in post-exilic material. This article focuses on the use of this name in what is generally accepted to be the youngest book in the Hebrew Bible, namely the book of Daniel. In Daniel 9, Moses' name appears in the construct form torat moshe (Law of Moses). After analysing this chapter from both a literary and a historical perspective and taking the results of this analysis into account, a suggestion is made regarding the reason why the compiler(s) of the book of Daniel may have used this phrase.
\end{abstract}

\section{Key Words: Book of Daniel; Pentateuch; Moses; Law of Moses; Daniel 9}

\section{Introduction}

In the early 1970s, roughly at the time Hendrik Bosman began his theological training, the winds of change started to blow in the field of Biblical Studies and, therefore, also Old Testament study. Internationally, the well-established historical-critical paradigm was being challenged from different quarters. In some sense, the presidential address of James Muilenberg, delivered right at the end of the previous decade in November 1969, gave impetus to this move away from what, at least in mainstream academia, had been seen as the only proper way to study the biblical text. ${ }^{3}$

At first, the shift from the classic historical-critical paradigm seemed only to open up an avenue to study the biblical text as a literary work, while specifically using the theories and methods applied in general literary study. This focus basically meant bracketing those historical questions that the historical-critical approach had been interested in for such a long time. Instead, the biblical text was studied with a new set of literary questions in mind that shifted the focus of scholars from what was happening 'behind' the text, to what was going on 'in' the text. However, at the same time, this change also created the possibility for recognising the subjective role of the researcher in the reading process. For instance, when the literary question related to the structure of a text was put on the table, more than one possibility presented itself. It became clear that 'the' structure of a text was not forthcoming from the text itself, but rather a product of the individual ingenuity of each interpreter of the text. Hence, a number of titles referring to 'a structure' of the text began to surface. Furthermore, existential questions posed by biblical scholars, especially from Africa and South America, related to social, political, and economic injustices augmented the participation of the reader in creating meaning when reading the biblical text.

It was during this transitionary time that the notion of intertextuality also became described and given a firm theoretical basis by, among others, philosophers like Judith Butler. ${ }^{4}$ Although the literature in this field is vast and the theory describing intertextuality deliberately crosses disciplinary boundaries, I present below a modest attempt to use this theoretical description in a rather loose manner in suggesting a possible reason for the name of Moses appearing in a construct form in the book of Daniel. 
In order to do so, the following scholarly consensus regarding the book of Daniel has to be noted at the outset:

- The book of Daniel is probably the last addition to a corpus of writing that later became the Hebrew Bible. ${ }^{5}$ In all likelihood, the book was compiled during, or in the aftermath of the persecution of the Jewish populace in Jerusalem during the reign of the Seleucid king, Antiochus Epiphanes (167-164 BCE).

- The book has similarities to other parts of what, at the time of the second quarter of the second century BCE, may have formed an authoritative corpus. The story of the wise sage at the court of a foreign king in Daniel 4 (Nebuchadnezzar's dream of a tree, his 'madness' and subsequent recovery) is, for instance, comparable to the Joseph story in Genesis $41{ }^{6}$

- A further example is the explicit reference to the prophet Jeremiah (Jer. 25:11-12; 29:10 - MT) in Daniel 9, where the exilic period spanning 70 years comes into focus. The Jeremiah source is indicated as part of 'the books' (hasefarim - Dan. 9:2), which, with reference to the prologue to Ben Sira, Collins ${ }^{7}$ presumes to be the books of the prophets.

- It is in this Chapter 9 that the name of Moses appears. As will be noted below, this chapter exhibits a number of peculiarities and interpretative challenges in the context of the book of Daniel as a whole.

- Both these references to the name Moses here form part of a fixed expression, i.e. "the law of Moses" (torat moshe ebed ha-elohim - 9:11; and torat moshe - 9:13).

In this article, the name Moses, is treated as it occurs in the text forming part of a genitive construct that links the name to the noun 'torah' (law). Thus the focus cannot fall only on the name or the person of Moses as such. In what follows, Daniel 9 will be discussed in more detail, while comparing the chapter to similar texts in the Hebrew Bible. This is followed by a discussion that sketches the broader context in which the book of Daniel is usually understood. On basis of this discussion, I shall relate the construct form 'torat moshe' in Daniel 9 to the broader context of the book.

\section{Daniel 9 in its Literary Context}

Firstly, this section deals with the chapter in which the name of Moses is mentioned in a synchronic manner or from a literary perspective. Daniel 9 is probably best-known for the response to the penitential prayer uttered by Daniel by the angelus interpres that characteristically appears in apocalyptic literature and here, is named Gabriel. The reason for Daniel's prayer, so the protagonist informs the reader (Dan. 9:2), is observed "in the books" as reference to a number of years noted by the prophet Jeremiah. This number, seventy years, is suggested to denote the desolation of Jerusalem during the exilic period. In his response to Daniel's request, Gabriel reinterprets this number not in a literal manner, but rather suggests it to mean 'seventy sevens', or in fact 490 years (thus, seventy weeks of years).

A lot has been written on this period of seventy weeks of years. Usually, studies in this regard pose questions related to when the period begins ${ }^{8}$ and ends; ${ }^{9}$ whether or not this number should be taken literally or symbolically; ${ }^{10}$ and the identity of the anointed rulers referred to in 9:25-26. ${ }^{11}$ Although all these issues are indeed interesting, partly because scholars have not arrived at any final solutions, they fall outside the scope of this specific section of the present study with its synchronic focus, and to some extent, also outside the focus of the article as a whole. 
Next, a few notes on the placement of this chapter in the final form of the Masoretic Text is made. As is well-known, the book of Daniel is written in two languages. Daniel 9 forms part of the last section of the book, which comprises three (apocalyptic) visions (Dan. $8: 1-12: 13$ ) and is written in Hebrew. The previous section, Daniel $2: 4 b-7: 28$, is written in Aramaic and contains five popular stories that are aptly referred to as court tales, or more specifically, as court legends ${ }^{12}$ and deals with the lives of the Jewish heroes, Daniel and his friends, at the courts of foreign kings (Dan. 2-6). This Aramaic part of the book also contains a vision (Dan. 7) that, although not written in Hebrew, is closely related to those later chapters as regards its visionary form and content. The first chapter of the book is introductory in nature and sets the broader background of the book, namely the $6^{\text {th }}$ century BCE exile. Daniel 1 also introduces the main characters and some of the themes and names that will be picked up again later in the book. ${ }^{13}$

Although the bilingual nature has perplexed scholars, the perplexity was reduced slightly when the structure of these three sections (Hebrew-Aramaic-Hebrew) was closely studied. In the early 1970s already, Lenglet proposes that the Aramaic part of the book is structured in an easily identifiable concentric style. ${ }^{14}$ According to his model, the form and content of Daniel 2 and 7 (the four empire scheme); Daniel 3 and 6 (persecution stories); and 4 and 5 ([different] outcomes related to human hubris) are strikingly similar. In a commentary on the book of Daniel, Goldingay proposes that a similar concentric structure is apparent in the first chapter of the book, ${ }^{15}$ possibly alerting readers to this pattern in the next Aramaic section (Daniel 2-7). In such a scheme, the central segment of the concentrically structured material is usually accentuated. In the opening Hebrew chapter, this central emphasis is the story of Daniel and his three friends' refusal to eat defiling food (vv. 8-16). In the Aramaic section (Dan. 2-7) the focus falls on the central chapters that both have as a theme, the pride of foreign rulers and its results.

In his book on the development of Rabbinic Judaism, Boccaccini proposes a similar concentric structure for the second Hebrew section of the book. ${ }^{16} \mathrm{He}$ goes on to remark, "Dan. 9 is the nucleus of the second section of the book (Dan. 8-12), and at the centre of ch. 9 is Daniel's prayer to God (9:4-19)" "His conclusion on this chapter that contains the only reference to Moses in the book reads, "Structurally and theologically, Dan. 9 plays a central role in the book of Daniel."18

The penitential prayer of Daniel, which is in turn the focal point of this central chapter in the last part of the book, invites comparison with similar prayers in Second Temple literature in especially the Masoretic Text. ${ }^{19}$ Universally, commentators on the book of Daniel refer to the following texts from the Hebrew Bible as being of similar sort: Ezra 9:615, Nehemiah 1:5-11; and Nehemiah 9:5-37 (cf. also Ps. 79). As noted elsewhere, these prayers share a number of formal characteristics, as well as fixed verbal expressions that can be viewed as the standard vocabulary of such prayers. ${ }^{20}$ The fact that so much material is shared by these texts led scholars to question the authenticity of the prayer in Daniel 9 as an original composition. In this paper, the focus is not on the issue of dependency, but rather a comparison between these texts, especially with regard to their use, or otherwise, of the expression 'torat moshe'.

Such a comparison yields the salient result that the name 'Moses' is not mentioned in all but one of these otherwise very similar prayers. First, though, we consider Ezra 9. Here the context is penitence for mixed-marriages among the people of Israel. Ezra 9:10b-12 reads: ${ }^{21}$

For we have forsaken your commandments [mitsot], which you commanded by your servants the prophets, saying... Therefore do not give your daughters to their sons, neither take their daughters for your sons ... 
This is a clear reference to Deuteronomy 7:3, however, in Ezra 9 the utterance is ascribed to "your servants, the prophets" and not directly to Moses, who is mentioned in Deuteronomy $5: 1$ as addressing the people of Israel. ${ }^{22}$

Also in Nehemiah 9:5-37, in a section that gives a detailed description of the exodus and Sinai events, the name of Moses is noticeably absent. Again, the only intermediaries that are mentioned are the prophets as a group $(9: 26,30)$ and the warnings they delivered to the people who did not adhere to these admonitions and were, therefore, subsequently punished. The noun 'law' is mentioned twice in this section, but then with a pronominal suffix indicating possession: "your [God's] law" (toratha/torateha) (Neh. 9:26, 34) and not linked to Moses as is the case in Daniel 9.

The only penitential prayer in the Hebrew Bible from the Second Temple period that mentions the name Moses, other than Daniel 9 that is, is the one in Nehemiah 1. However, here the link between Moses and the commandments (or statutes) is expressed as that of a mediator (vv. 7-8):

We have offended you deeply, failing to keep the commandments, the statutes, and the ordinances that you commanded your servant Moses. Remember the word that you commanded your servant Moses, 'If you are unfaithful, I will scatter you among the peoples.

Although the references to Deuteronomy (Deut. 4:27; 30:2) are quite apparent in these lines, the word torah is not used.

It seems that one can conclude that the phrase torat moshe is a unique phrase in the literary context of a penitential prayer in Daniel $9 .^{23}$ If this is the case, we should inquire about the unique function of this expression in the book of Daniel. To answer this question, a look at the book from a diachronic perspective is necessary.

\section{The Book of Daniel in Historical Context}

It is almost universally accepted among scholars that the book of Daniel, in its present form, was composed during the 2nd Century BCE during the time of religious persecution under the Seleucid reign of Antiochus IV Epiphanes. ${ }^{24}$ His career began in a very modest mode as a political hostage of the Roman Republic ${ }^{25}$ that held him in custody in order to keep the reigning Greek family in Palestine in check. After his father, Antiochus III, died, he was succeeded by another son and older brother of Antiochus IV, namely Seleucus IV. This event also meant that Antiochus IV was replaced as a hostage in Rome by his nephew and son of Seleucus IV, named Demetrius I. Subsequently, Seleucus IV was murdered by a usurper, Heliodorus, but Antiochus IV managed to reclaim the throne for the family. ${ }^{26} \mathrm{With}$ the rightful heir still in Rome, Antiochus declared himself co-regent along with an infant brother of Demetrius I, also named Antiochus. Antiochus IV Epiphanes arranged for his younger nephew and co-regent to be murdered after only a few years.

As sole regent, Antiochus then set his sights on the Ptolemaic Empire in the southwest in order to expand his influence. After limited success during a first invasion, Antiochus launched another onslaught against Egypt in $168 \mathrm{BCE}$, only to be halted in his march by the Roman ambassador drawing what became the proverbial "line in the sand". ${ }^{27}$ During this second campaign, a rumour reached Jerusalem that Antiochus IV had lost his life. The news set in motion a chain of events in Jerusalem that were in the making for some time.

When Antiochus IV came to power in 175 BCE, Onias III held the highest religious office in Jerusalem. However, his brother Jason offered Antiochus a sum of money to be named High Priest in Onias' stead. The emperor accepted the offer, but three years later, 
Menelaus persuaded Antiochus with the promise of an even higher bid to be named High Priest, probably to curb the Hellenization process somewhat. This caused Jason to flee from Jerusalem, only to return on hearing the false rumour of Antiochus' death, and in order to claim back the office he had to vacate. The subsequent unrest in Jerusalem led to Antiochus cracking down on the Jewish population; killing thousands and committing sacrilege in the temple in 167 BCE. ${ }^{28}$ Only three years later, after a successful Maccabean uprising, was the temple rededicated.

Why then, did someone, or more probably a group of people decide to create the book of Daniel in the wake of these events? Instead of trying to find an answer to the question for whom the book was written, this article explores against whom it was written. In any society it is rare to find two groups that are so diametrically opposed to each other that they do not share any common ground. In order to be recognised as the more influential of the two, a group has to win over followers by means of a more persuasive analysis of current events and an apt response to such events. What is outlined below builds on the premise that these ancient texts were produced by groups in the upper strata of society as part of struggle among these groups to promote their understanding of and remedy for a challenging period in their history.

The book of Daniel was not necessarily written against an outside force, e.g. Antiochus IV, the Hellenizing programme of the Seleucids ${ }^{29}$ or influential Jews who supported it. Furthermore, we need to question the often-cited idea that this book was compiled first and foremost to provide comfort for people during a time of persecution. When people's lives are threatened on the basis of their identity, in this instance being Jewish in $2^{\text {nd }}$ century BCE Jerusalem, a good read is probably the last thing on the minds of such a community. The book of Daniel should rather be viewed as voicing specific answers in what may be seen as an inner-group (Jewish) debate dealing with reasons for and reactions to times of severe strife that befell this community at that time. As such, the book is to be seen more along the lines of a polemic against other inner-group voices rather than an attempt at attacking an outside force.

The 'other' group that the book of Daniel is most probably responding to is the Maccabees who played a decisive role in the aftermath of the persecution by Antiochus IV and the sacrilegious acts committed by his soldiers. This identification is of course not novel and in previous scholarship the following reasons have been provided for this identification:

- The book of Daniel depicts a non-militant, quietist response to the $2^{\text {nd }}$ century uproar, whereas the Maccabees were of different, more militant persuasion; ${ }^{30}$

- The book of Daniel does not refer to the rededication of the temple in 164 BCE; a feature that is usually taken to indicate a terminus ad quem for the writing of the book of Daniel; ${ }^{31}$

- If scholars are correct in assuming the "little help" mentioned in 11:34 refers to the Maccabees, it is clear why the compilers of Daniel are silent on the rededication of the temple. Alluding to that event will be a concession that the ideas and tactics of the 'opposition' won the day.

Continuing this line of argument, it will be helpful to compare the texts of Daniel and 1 Maccabees in order to highlight further divergences between these two groups. ${ }^{32}$ The text of 1 Maccabees dates from the time when the Hasmonean dynasty was firmly established, most probably no later than the beginning of the first century BCE. This is at least one and probably two generations after the gloomy events surrounding the person of Antiochus IV. However, it is still possible to glean at least some insight from the text that may reflect the 
sentiments of an earlier generation. At the time of writing, these ideas probably would have become even more rigid.

Reference was made above to the central story in the introductory chapter of the book of Daniel. In this story, Daniel objects to eating the food provided by the king, an action seconded by his three followers, as part of their training at the Babylonian court (Dan. 1:8, 10). Collins remarks, "Daniel's objection to the royal food is in the spirit of the biblical laws insofar as it is concerned with purity and defilement, even though it goes beyond the specific prohibitions of the Torah." 33 The link with 1 Macc. 1:62-63 has been noted often:

Howbeit many in Israel were fully resolved and confirmed in themselves not to eat any unclean thing. Wherefore they prefer rather to die, that they might not be defiled with meats, and that they might not profane the holy covenant: so then they died.

Although the text in Daniel is silent on punishment for disobeying the food instruction set by the king, the tenor in the narrative, captured by the words of the chief eunuch (Dan. 1:10), remains threatening (italics added):

The palace master said to Daniel, "I am afraid of my lord the king; he has appointed your food and your drink. If he should see you in poorer condition than the other young men of your own age, you would endanger my head with the king."

At the same time, this narrative in Daniel is flanked by two concentric panels (Dan. 1:3-7; 17-20) that exhibit a less rigid view of Jewish identity than what is found in 1 Maccabees. In the latter text we read the following about Judas Maccabeus: "Moreover he went through the cities of Judah, destroying the ungodly out of them, and turning away wrath from Israel" (1 Macc. 3:8). It has been argued that in Maccabean thought anyone seen as an opponent becomes a renegade equated with foreigners and the nations. ${ }^{34}$ It seems that Daniel agrees with regard to the issue of food and setting oneself apart from others, at least in respect of diet. However, from the opening chapter of the book of Daniel, it is clear that in dealing with Gentiles from a position of subservience, the acceptance of cultural changes (e.g. language and names) as well as cooperating with a foreign ruler can produce positive results in the long run.

The introductory chapter of the book of Daniel sets the tone for the rest of the book. It points out that this group, while firmly connected to its Jewish identity, does have a broader view on some issues related to identity than is perhaps the case with the Maccabees. The text of Daniel even refers to a more fervent outlook than that of the Maccabees when it comes to the issue of persecution. In 1 Maccabees 2:41 we read about the decision taken under the leadership of Mattathias that the Jews will defend themselves on a Sabbath lest they all die:

And on that day, they took counsel, saying, "Let us make a war against every human who wars against us on the day of the Sabbaths, so that we may not all die as our brothers died in the hiding places."

In the narrative, this decision follows after the description of group martyrdom in which many Jews were killed on the Sabbath day because they did not offer any resistance against the soldiers of the king (1 Macc. 2:31-38).

This resolution to resist an attack on the Sabbath day stands in stark contrast with the persecution story in Daniel 3. In the concentrically structured Aramaic section of the book, this chapter has its parallel in Daniel 6 where Daniel, as individual, is thrown into the lion's pit for upholding his religious convictions and customs. The issue of group martyrdom is emphasised in Daniel 3. Here, the group of three friends bravely declares that even if their god is not able to rescue them from the fiery furnace, they shall not adhere to the king's 
prohibition preventing them from fulfilling their religious commitments. When it comes to group martyrdom, such a rigid view was apparently rejected by the Maccabees in favour of a more pragmatic approach.

To summarise: it seems as if the narrative section in the book of Daniel discloses specific issues that indicate the group responsible for this book to have dissimilar sentiments compared to the Maccabees on issues of enculturation (i.e. accepting some foreign cultural elements) and resistance. As regards the former, the text reveals a more relaxed view in accepting some form of cultural adaptation; whereas regarding the latter, the book of Daniel portrays a more pious stance in that it seems to defend the idea of group martyrdom. Hence, the group responsible for the book of Daniel does not want to be seen as inferior to their major contender vying for allegiance during the second quarter of the $2^{\text {nd }}$ Century BCE. With regards to diet, they agreed to set themselves apart by even expanding on the dietary regulations of the Torah. When it comes to the issue of group martyrdom, the Daniel group is even more pious than the picture of the Maccabees portrayed in 1 Maccabees. The Daniel group's positive outlook regarding group martyrdom may have been fuelled by their newly-developed idea of a resurrection of the dead (Dan. 12:2-3).

\section{The 'torat moshe' in a New Light}

We have already noted that the expression torat moshe found in Daniel 9 does not appear in similar penitential prayer texts from the Second Temple period, specifically those in the Hebrew Bible composed during this period. Drawing on the insights above, this section deals with the question why the text of Daniel 9 uses this phrase and not the expressions usually found in such prayers, such as 'your law'; or to quote an extended form from a different genre "the book of the law of Moses" (Neh. 8:1). More especially in a formulaic text like a penitential prayer, the expectation is to find similarities with regard to such traditional material.

An obvious reason for this diversion may be that at the time when the book of Daniel was compiled, torat moshe was the general term for the torah as such. However, this points to yet another difference with 1 Maccabees, where despite this group's obvious zeal for the law and keeping the traditions of old intact, this expression is not used once. Furthermore, the book of Daniel has gained somewhat of a notorious reputation for obvious answers not necessarily being the only answers, let alone the correct ones. Thus, this article ventures the following tentative notion:

The expression torat moshe was (re)introduced by the authors of the book of Daniel to highlight a specific take on the law. In Daniel 9 we find an expression of communal penitence. In a shift from the drift found in the Deuteronomist History, it is not the leaders who are to blame for the calamities that befell the people. Indeed, all the people of the land stand guilty $(9: 6-7,11)$. In this way, the book, to some extent, links up with what Boccaccini (2002:79-80) describes as Zadokite Judaism. In this line of thought there is a stronger sense of personal responsibility compared to that of the Deuteronomists. So, if all people suffer, it means that all people must have transgressed in some way.

However, the response of the Daniel group differs strikingly from that of the Maccabees. Unlike the Maccabees, this group's suggested action is in fact, inaction. They believe the eternal kingdom of God will come about without the involvement of human hands (Dan. $2: 34,45)$. In contrast to the militancy of the Maccabees, the Daniel group seeks a more 'spiritual' manner in which to resolve the crises they are facing. Taking their cue from the development in Zadokite Judaism to focus on individual responsibility and accountability, 
penitence is proposed by all involved in misconduct. However, in Daniel 9 this is done through a single spokesperson who mediates on their behalf to receive atonement for their wrongdoings. As such, this recalls the mediatory role of the character Moses between God and the people in the polemic against Aaron during the Golden Calf episode (Ex. 32:11-14).

It is suggested that the phrase torat moshe is used in Daniel 9 to recall a more compassionate understanding of the law according to which, amid transgression there is always the opportunity for pious intervention on behalf of the people. This stance is far removed from the more zealous exploits of the Maccabees taking it upon themselves to act on behalf of the disgruntled God to cleanse the people (1 Macc. 2:42-44). In Daniel 9, the reader witnesses the emphasis on the tradition of Moses as true mediator to atone for transgressions. This during a time when according to Boccaccini (2002:80), "[i]n the Zadokite worldview ... Aaron has superseded Moses."

\section{Conclusion}

The phrase torat moshe is used by the Daniel group in Jewish society around the middle of the $2^{\text {nd }}$ Century BCE to set themselves apart from other groups vying for support during a time of national crisis. In opting for this term, they not only emphasise their commitment to the law, but also lay claim to the Mosaic tradition, which they interpreted to be more focused on pious penitence than on zealous retribution as demonstrated by the Maccabees.

\section{BIBLIOGRAPHY}

Athas, George. "In Search of the Seventy 'Weeks' of Daniel 9," The Journal of Hebrew Scriptures, 9(2) (2009). doi: http://dx.doi.org/10.5508/jhs.2009.v9.a2.

Balentine, Samuel E. "I was ready to be sought out by those who did not ask." Pages 1-20 in Seeking the Favor of God (vol. 1): The origins of Penitential Prayer in Second Temple Judaism. Edited by Mark J. Boda, Daniel K. Falk and Rodney A. Werline. Atlanta: Society of Biblical Literature, 2006.

Bickerman, Elias J. The God of the Maccabees: Studies on the Meaning and Origin of the Maccabean Revolt. Leiden: Brill, 1979.

Boccaccini, Gabriele. Roots of Rabbinic Judaism. Grand Rapids: Eerdmans, 2002.

Bosman, Hendrik. "Remembering Moses as a Model of Israelite and Early Jewish Identity," Scriptura 96 (2007):326-33.

Clines, David J.A. The Bible and the Modern World. Sheffield: Phoenix Press, 2005.

Collins, John J. Daniel: With an Introduction to Apocalyptic Literature (FOTL 20). Grand Rapids: Eerdmans, 1984.

Collins, John J. Daniel (Hermeneia). Minneapolis: Fortress, 1993.

Goldingay, John. Daniel (WBC 30). Dallas: Word, 1989.

Grabbe, Lester L. An Introduction to Second Temple Judaism. London: Bloomsbury, 2012. Gruen, Erich S. "Hellenism and Persecution: Antiochus IV and the Jews." Pages 238-64 in Hellenistic History and Culture. Edited by Peter Green. Oakland: University of California Press, 1996.

Hartman, Louis F. and Di Lella, Alexander A. The Book of Daniel (AB 23). New York: Doubleday, 1978. 
Hess, Richard S. “The Seventy Sevens of Daniel 9: a Timetable for the Future?" Bulletin for Biblical Research, 21(3) (2011):315-30.

Juvan, Marko. History and Poetics of Intertextuality. West Lafayette: Perdue University Press, 2008.

Kia, Mehrdad. The Persian Empire. A Historical Encyclopedia. Santa Barbara: ABC-Clio, 2016.

Lenglet, André. “La Structure littéraire de Daniel 2-7,” Biblica 53 (1972):169-90.

Meadowcroft, Timothy. "Exploring the Dismal Swamp: The Identity of the Anointed One in Daniel 9:24-27," Journal of Biblical Literature 120(3) (2001):429-49.

Portier-Young, Anathea E. Apocalypse Against Empire: Theologies of Resistance in Early Judaism. Grand Rapids: Eerdmans, 2014.

Redditt, Paul L. Introduction to the Prophets. Grand Rapids: Eerdmans, 2008.

Sarason, Richard S. "The Persistence and Trajectories of Penitential Prayer in Rabbinic Judaism." Pages 1-38 in Seeking the Favor of God (vol. 3): The impact of Penitential Prayer beyond Second Temple Judaism. Edited by Mark J Boda, Daniel K. Falk and Rodney A. Werline. Atlanta: Society of Biblical Literature, 2008.

Shea, William H. "When did the seventy weeks of Daniel 9: 24 begin?" Journal of the Adventist Theological Society, 2(1) (1991):115-38.

Van Deventer, Hans J.M. "Suffering, Psalms and Allusion in Daniel 9," Old Testament Essays, 25(1) (2012):207-26.

\section{Endnotes}

1 It is a great pleasure to present this contribution to our colleague Hendrik Bosman. Over the two decades that I have known Bossie, he has been a true role model of what it means to be an academic: well conversant with the philosophical foundations in a field; eager to explore new intellectual horizons (geographical and culinary horizons may be added here, as a visit to Nigeria comes to mind); a willing and soft-spoken mentor, but one who can also pack a serious intellectual punch if one enters a discussion ill-prepared. In this contribution, I honour the work of Prof. Bosman by relating the book of Daniel to one of his fields of expertise, namely the Pentateuch.

2 The financial assistance of the National Research Foundation (NRF) through Incentive Funding for Rated Researchers is hereby acknowledged. The research results do not necessarily reflect the view of the NRF. David J.A. Clines, The Bible and the Modern World (Sheffield: Phoenix Press, 2005), 12.

$4 \quad$ Marko Juvan, History and Poetics of Intertextuality (West Lafayette: Perdue University Press, 2008$), 179$.

5 Louis F. Hartman and Alexander A Di Lella, The Book of Daniel (AB 23; New York: Doubleday, 1978), 25, thus argue that "because the book appeared so late (second quarter of the second century B.C.) it could not be included in the prophetic corpus." In a more detailed discussion of the redaction history of the Book of Daniel, John J. Collins, Daniel (Hermeneia; Minneapolis: Fortress, 1993), 38, concludes that the last glosses added to the book (in chapter 12) were "added before the rededication of the temple."

6 Daniel 2 narrates a parallel story, but the story in Daniel 4 is in all probability the oldest as it has a less complex plot and structure compared to Daniel 2.

7 Collins, Daniel, 348.

$8 \quad$ William H. Shea, "When did the seventy weeks of Daniel 9:24 begin?" Journal of the Adventist Theological Society 2(1) (1991):115-38.

9 George Athas, "In Search of the Seventy 'Weeks' of Daniel 9," The Journal of Hebrew Scriptures 9(2) (2009). doi: http://dx.doi.org/10.5508/jhs.2009.v9.a2.

10 Richard S. Hess, "The Seventy Sevens of Daniel 9: a Timetable for the Future?" Bulletin for Biblical Research 21(3) (2011):315-30.

11 Timothy Meadowcroft, "Exploring the Dismal Swamp: The Identity of the Anointed One in Daniel 9:24-27," Journal of Biblical Literature 120(3) (2001):429-49. 
Collins, John J. Daniel: With an Introduction to Apocalyptic Literature (FOTL 20) Grand Rapids: Eerdmans, 1984), 42.

13 To mention a few: "the vessels of the house of God" (Dan. 1: 2) forms part of the storyline in Daniel 5 (vv. 2 3); resistance to official orders (Dan. 1: 8ff) is taken up in the martyr stories of Daniel 3 and 6, while the Persian king, who eventually ended the exile, Cyrus (Dan. 1:21), is linked to the time of Daniel's final vision in chapter 10.

14 André Lenglet, “La Structure littéraire de Daniel 2-7," Biblica 53 (1972):169-90.

15 John Goldingay, Daniel (WBC 30; Dallas: Word, 1989), 8.

16 Gabriele Boccaccini, Roots of Rabbinic Judaism (Grand Rapids: Eerdmans, 2002), 171.

17 Boccaccini, Rabbinic Judaism, 181.

18 Boccaccini, Rabbinic Judaism, 188.

19 As will be noted later in the argument, the term torat moshe is peculiar in the context of penitential prayers in the Hebrew Bible. Extending the scope to later material outside the Hebrew Bible seems to render a similar result. In the Book of Baruch, this term is used (Bar 2:2) in a narrative section flanked by a penitential prayer (1:15-21) and a prayer for deliverance (2:11-32). Although words and expressions similar to Daniel 9 are attested in especially the penitential prayer (Bar. 1:15-21) the term toi nomoi mousé is not found in that context. The same holds true for prayer texts from Qumran. For a discussion of Qumran texts, see Samuel E. Balentine, "II was ready to be sought out by those who did not ask," in Seeking the Favor of God (vol. 1): The origins of Penitential Prayer in Second Temple Judaism (eds. Mark J Boda, Daniel K. Falk and Rodney A. Werline (Atlanta: Society of Biblical Literature, 2006), 1-20. The term torat moshe appears in the Community Rule (1QS), but, again, not in the context of a penitential prayer. Richard S. Sarason, "The Persistence and Trajectories of Penitential Prayer in Rabbinic Judaism," in Seeking the Favor of God (vol. 3): The impact of Penitential Prayer beyond Second Temple Judaism, eds. Mark J Boda, Daniel K. Falk and Rodney A. Werline (Atlanta: Society of Biblical Literature, 2008), 25, cites a single occurrence of this expression later Talmudic literature in $m$. Yoma 6:2 where it is related to the High Priets's confession on the Day of Atonement.

Hans J.M. Van Deventer, "Suffering, Psalms and allusion in Daniel 9," Old Testament Essays, 25(1) (2012):207-26.

21 Unless stated otherwise, all biblical quotes are taken from the NRSV.

22 As regards the portrayal of Moses in the Deuteronomistic tradition, Hendrik Bosman, "Remembering Moses as a Model of Israelite and Early Jewish Identity," Scriptura, 96 (2007):329, remarks the following: "In Deuteronomy 1-11 the Decalogue in chapter 5 is framed and interpreted by motivational speeches by Moses recalling events in the history of Israel." Thus it is strange that Ezra 9 does not present the character of Moses explicitly.

23 To be sure, the exact expression does occur in a number of places outside this genre restriction, namely: Joshua 8:32; 1 Kings 2:3; 2 Kings 23:25; 2 Chronicles 23:18; 2 Chronicles 30:16; Ezra 3:2; Ezra 7:6; whereas the more extended form "book of the law of Moses" is attested to in Joshua 8:31; Joshua 23:6; 2 Kings 14:6; and Nehemiah 8:1.

Collins, Daniel, 38.

25 Mehrdad Kia, The Persian Empire. A Historical Encyclopedia (Santa Barbara: ABC-Clio, 2016), 303.

26 Lester L. Grabbe, An Introduction to Second Temple Judaism (London: Bloomsbury, 2012), 10.

27 Erich S. Gruen, "Hellenism and Persecution: Antiochus IV and the Jews," in Hellenistic History and Culture, ed. Peter Green (Oakland: University of California Press, 1996), 238-264 (245).

Anathea E. Portier-Young, Apocalypse Against Empire: Theologies of Resistance in Early Judaism (Grand Rapids: Eerdmans, 2014), 117-30.

29 Goldingay, Daniel, 329, states as much: "Daniel suggests no polemic against Hellenistic culture of lifestyle as such."

30 Hartman and Lella, The Book of Daniel, 43-45.

31 Paul L Redditt, Introduction to the Prophets (Grand Rapids: Eerdmans, 2008), 180.

32 This comparison takes into account that these texts do not necessarily refer to real life events and situations and are ideologically infused as regards their contents. However, it is exactly this aspect that makes these texts good sources to gauge pertinent differences between the groups responsible for their writing. Furthermore, it is recognised that the dates of these texts put them between 50 to 100 years apart with the book of Daniel being completed before the Hasmonean period and 1 Maccabees probably only towards the end of that epoch. Collins, Daniel, 142.

34 Elias J. Bickerman, The God of the Maccabees: Studies on the Meaning and Origin of the Maccabean Revolt (Leiden: Brill, 1979), 19. 